ACTA AGROBOTANICA

Vol. 59, z. 12006

s. 233239

\title{
Large-scale vs. small-scale factors affecting flowering patterns in Senecio macrophyllus M.BIEB., a long-lived perennial
}

\section{BOŻENNA CZARNECKA}

\author{
Zakład Ekologii, Uniwersytet Marii Curie Skłodowskiej, ul. Akademicka 19, 20033 Lublin \\ e mail: boczar@biotop.umcs.lublin.pl
}

(Received: 14.06.2005)

\section{Sum mary}

The aim of the study was to establish which of environmental factors affect flowering patterns in a long-lived herbaceous plant Senecio macrophyllus. The study was conducted in the population of Biała Góra (White Mountain) near Tomaszów Lubelski in the years 1989-2004. The results allow to conclude that in the reproductive patterns of the analysed population small-scale environmental factors (soil moisture and trophism, light intensity) are more important than large-scale climatic factors (temperature, precipitation), which to a comparable extent affect the plants in the whole population area.

Key words: flowering patterns, large scale factors, small scale factors, reproduction, perennial plant, Senecio macrophyllus

\section{INTRODUCTION}

Patterns of flowering, considered in population biology as variation in flowering frequency between subsequent years both at the individual (i.e. genet) level, and at the population level, are important for understanding the life history of long-lived perennials (I $\mathrm{nghe}$ and T $\mathrm{m} \mathrm{m}, 1988$ ). They are different for different plant groups. Best investigated are the flowering patterns of tree species, which exhibit a type of stable periodic fluctuations, known as mast flowering or mast seeding ( $\mathrm{S}$ a t a k e and I w a s a, 2000; I w a s a and S a t a k e, 2004; S a t a k e, 2004). In the case of perennial herbaceous plants, especially orchids, flowering patterns are either irregular, or unpredictable in nature (Inghe and Tamm, 1988; Kindlmann and Balounová, 1999; B r z o s k o, 2002). 
This study aims at determining: (1) which of environmental factors largescale climatic factors (such as temperature and precipitation), or rather heterogeneous biotope conditions (soil trophism, moisture and light intensity) affect flowering patterns of a perennial herbaceous plant; and (2) if different patterns of generative reproduction can be realised within the limits of a particular population area.

\section{MATERIAL AND METHODS}

Senecio macrophyllus M. BIEB., formerly known as S. umbrosus (Asteraceae), a rare element of Central European flora, was chosen as a model object of the study. It is a large, iteropareus (polycarpic) rhizomatous plant with erect flowering stem up to $190 \mathrm{~cm}$ high and inflorescence (subcorymb) consisting of numerous capitula (up to 180). It is visited by many pollen-feeding insects, particularly Lepidoptera, Hymenoptera and Diptera. S. macrophyllus has a very slow individual development and long life cycle (C z a r n e c k a , 1995, 1998, 2000). It appears only at several localities in south-eastern Poland. S. macrophyllus grows on proper, brown and chernozem rendzinas on xerothermic slopes and small chalk islets within calcareous fens. The species was included into the Polish Red Data Book (C zarneck a and K u ch ar c z y k, 2001).

The study was conducted in the S. macrophyllus population of Biała Góra (White Mountain) near Tomaszów Lubelski in the years 1989-2004. It focused on the determining of flowering patterns at the individual level, analysing patterns of reproductive episodes in the sample of 200 marked genets. Flowering frequency of particular genets of S. macrophyllus was assessed, as well as the breaks between these periods. Each year the percentage of flowering plants in the sample of all mature individuals was measured, including these juvenile and immature plants which in the following years reached more advanced stages of development. Similarly, I analysed the correlation between the flowering intensity and meteorological conditions in the respective years (mean annual temperature and annual precipitation sum, compared to the mean values in the years 1951-2000). The study compared flowering patterns of plants growing in two types of microhabitats: in patches of low, loose and sun-exposed grassland dominated by Aster amellus, Carex flacca and Teucrium chamaedrys, and in taller, denser grassland with the dominant Brachypodium pinnatum and Peucedanum cervaria shaded by a loose tree stand.

\section{RESULTS}

No clear correlation was found between the flowering intensity and meteorological conditions in the subsequent years of the study (Fig. 1). Yet, there could be observed different flowering patterns of individuals growing in two different microhabitats. In the patches of low, unshaded grassland the plants realised the flowering pattern of fluctuation character with several periods of intensive flowering (Fig. 2A). The highest proportion of flowering to nonflowering genets $(\mathrm{F}: \mathrm{NF}=1: 1.29)$ was observed 


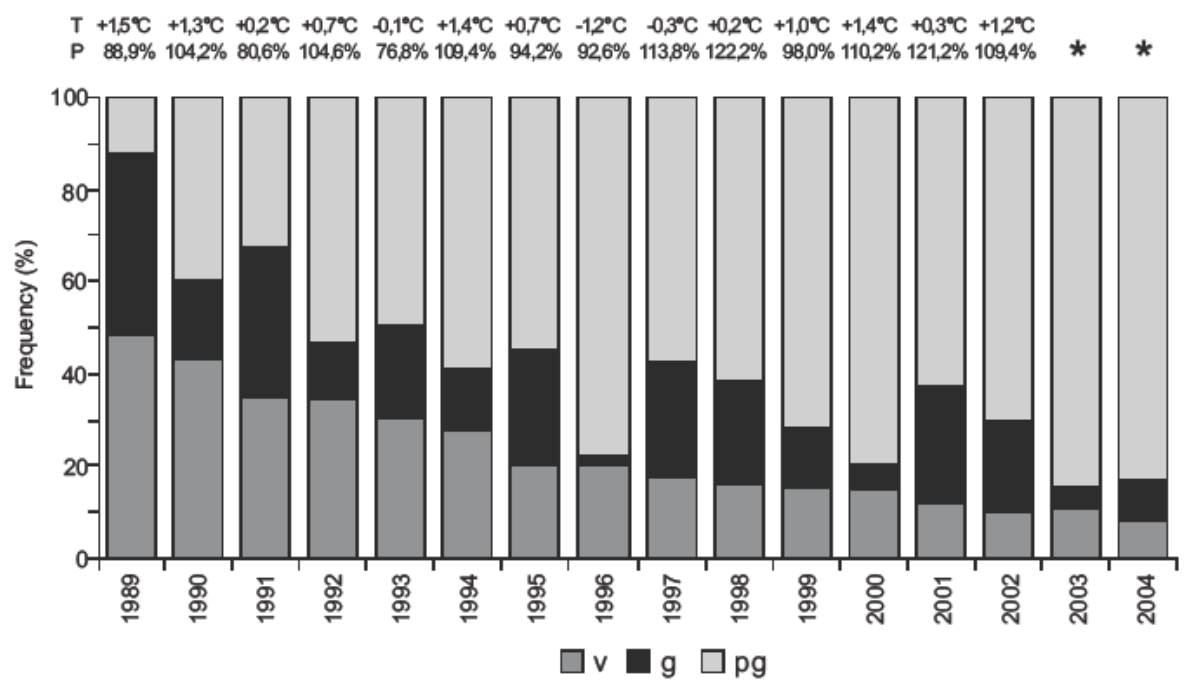

Fig. 1. Flowering pattems of Senecio macrophyllus on the background of selected climatic factors: T yearly temperature (value deviations from the mean value in the years 19512002 ), $P$ precipitation (in per cent of the mean value in the years 1951 2002). All mature genets were taken into account each year: $v$ pre reproductive vegetative (= virginile) plants, g generative plants, pg post generative (= resting) plants. * lack of data.
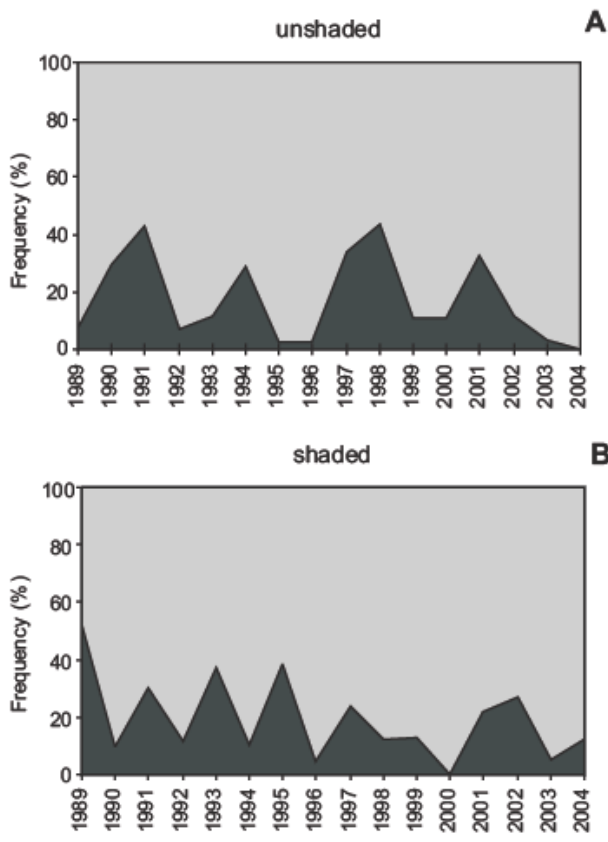

B

a $\square \mathrm{NF}$

Fig. 2. The share of flowering (F) and nonflowering (NF) mature genets of Senecio macrophyllus in the years 19892004. 
in 1998, no flowering in 2004. In the shaded patches of tall and dense grassland 7 periods of intense flowering were observed: 4 periods in the years 1989-1995, every second year (stable limit cycle pattern), and 3 periods in the years 1997 and 20012002, separated by breaks of several years, and therefore realising the fluctuation pattern (Fig. 2B). Maximum flowering ( $F: N F=1: 0.92)$ was observed in 1989, no flowering at all in 2000.

Altogether 145 genets flowered, which means that the original group of 72 plants in 1989 (55 in generative stage and 17 in post-reproductive stage) was joined by the following 73 plants which at the beginning of the study had exhibited various stages of vegetative growth. In total, 380 reproductive episodes were observed. Out of the 145 genets, the majority of 97 (66.9\%) flowered 1-3 times, 35 plants (24.1\%) flowered 4-5 times, and only 13 of them (9.0\%) flowered more than 5 times (observed maximum: 9 times, of single plant in shaded location). Particular plants flowered in very different time periods. In total there were observed only 20 cases of reproductive episodes in the subsequent 2 years, and only 2 cases of flowering in consecutive 3 seasons; all of them in 17 genets. The longest observed break between flowering periods was 12 years; at the same time 10 breaks that had already lasted 13-15 years were noticed, too.

\section{DISCUSSION}

In population biology, the advantages of flowering synchrony are believed to lie in the increase of the plant pollination and its effectiveness, especially in the case of anemogamous plants. It also lowers the level of seed predation by specialised insects while the number of flowering and fruiting plants increases (Ke $11 \mathrm{y}, 1994$; I s a $\mathrm{i}$ et al., 1997; M c K o ne et al., 1998; Kelly and S ork, 2002; Crone and Lesic a, 2004).

Relatively popular is the belief that the major factors triggering off the synchronized reproduction are the climatic ones, chiefly precipitation, temperature and the warmth sum resulting from the latter (P o s t, 2003; S a t a k e, 2004). However, in the analysed population of Senecio macrophyllus the clear correlation between flowering and meteorological conditions observed in the year of flowering, or in the preceding one, has not been found. During 14 years, 6 very warm seasons were observed (with the temperature $1-1.5^{\circ} \mathrm{C}$ higher than the long-period average) and 3 seasons relatively dry (less than $90 \%$ of the long-period average precipitation), but in one season only (1989) these two deviations from the mean values coincided. The smallest percentage of flowering plants was observed in the years 1996, 2000 and 2003; however, each of these periods was different in respect to the analysed parameters. According to Scandinavian studies, even species belonging to the same biological group and appearing at the same environment response very differently to climatic factors (I $\mathrm{g} \mathrm{h}$ e and T a m m, 1988). Similar conclusions can be drawn from the studies of the steppes of Kazakhstan (Vorontzova and Zaugolnova, 1985). It seems that even the correlation between the flowering intensity of $S$. macrophyllus 
and the course of weather conditions in subsequent months of each year, does not necessarily have to bring the conclusion to the analysed problem.

The lack of reproduction synchrony in the whole population of insect-pollinated S. macrophyllus marks this species as strikingly different from wind-pollinated species, both woody and herbal, whose synchrony, at least on a local scale, is conditioned by the exchange of pollen among the neighbouring plants (I s a g i et al., 1997; M c K on e et al., 1998; S a take and I w a s a, 2000, 2002; S a ta ke, 2004). Different flowering patterns in two different microhabitats point to the role performed by habitat mosaicism in the population area. The higher frequency of flowering observed in the lightly shaded areas, at least in the initial period of the study, seems to be related to their more favourable environmental conditions (moisture and soil trophism), in comparison to the sun-exposed locations. As it has been shown earlier $(\mathrm{C} \mathrm{z}$ a r n e c $\mathrm{k} a, 1995)$, under the shade of loose tree stands, in the patches of denser and taller grassland, there develop medium-deep calcareous rendzinas with ca. $6 \%$ of organic carbon content. On the unshaded slopes overgrown with loose grasslands, rendzinas are very shallow (merely rubble at places), with a smaller content of organic carbon (ca. 2\%), nitrogen nitrate and magnesium. It is worth pointing to one more important factor differentiating the two analysed habitats: namely to the light intensity, several times higher in the sun-exposed areas than in the shaded ones (on a sunny day it is 45000-50 $000 \mathrm{~lx}$ and $5000-15000 \mathrm{~lx}$, respectively), and UV radiation connected with it, especially UV-B. As Grammatikopou lo s et al. (2001) have shown, the use of anti-UV filters had changed the flowering patterns of the Mediterranean species of Rosmarinus officinalis. In the case of $S$. macrophyllus the role of such a filter may be performed by a loose canopy of trees shading plants from the damaging radiation.

The results of the study allow me to conclude that in the reproductive patterns of the analysed population of $S$. macrophyllus these are small-scale environmental factors that are more important and that shape the condition of an individual, rather than large-scale factors, which to a comparable extent affect the plants in the whole population area.

\section{Aknowledgements}

My thanks goes to Prof. B. M. Kaszewski for the data on climatic factors and to P. Dzirba, M.Sc. for preparing figures.

\section{REFERENCES}

B rzos k o E., 2002. Dynamics of island populations of Cypripedium calceolus in the Biebrza river valley (north east Poland). Bot. J. Lin. Soc. 139: 677.

Crone E. E., Le si c a P., 2004. Causes of synchronous flowering in Astragalus scaphoides, an iteroparous plant. Ecology, 85: 19441954. 
Czarnecka B., 1995. Biology and ecology of the island populations of Senecio rivularis (Waldst. et Kit.) DC. and Senecio umbrosus Waldst. et Kit. Rozpr. Wydziału Biologii i Nauk o Ziemi. Rozpr. habil. 48, Wyd. Univ. Mariae Curie Skłodowska, pp. 262 (in Polish with English summary).

C z a r n e c k a B., 1998. Patterns of plant growth and population spatial dynamics. [In:] Popula tion Biology and Vegetation Processes. K. Falińska (ed.). W. Szafer Institute of Botany, Polish Academy of Sciences, Kraków, pp. 274289.

C z a rne k a B., 2000. Space and time in clonal plants: studies on Iris aphylla and Senecio umbrosus. [In:] Plant Population Biology VI. P. Eliaš (ed.). SEKOS, Bratislava Nitra, pp. 1725.

C z a r n e c k a B., K u c h a r c z y k M., 2001. Senecio macrophyllus M. BIEB. starzec wielko listny. [In:] Polish Red Data Book of Plants. Pteridophytes and Flowering Plants. R. Kaźmierczakowa, K. Zarzycki (eds.). W. Szafer Institute of Botany, Institute of Nature Conservation, Polish Academy of Sciences, Kraków, pp. 375377.

Grammatikopoulos G., Drillas P., Kyparissis A., Petropoulou Y., Mane $\mathrm{t}$ a s Y., 2001. Reduction of ambient UV B radiation does not affect growth but may change the flowering pattern of Rosmarinus officinalis L. Plant Ecol. 154: 119122.

Inghe O., Tamm C. O., 1988. Survival and flowering of perennial herbs. V. Patterns of flowering. Oikos 51: 203219.

Is ag i Y., Sugimura K., Sumida A., I to H., 1997. How does masting happen and synchronize? J. Theor. Biol. 187: 231239.

Iw a s a Y., S at a ke A., 2004. Mechanisms inducing spatially extended synchrony in mast seeding: the role of pollen coupling and environmental fluctuation. Ecol. Res. 19, 13-20.

Ke 11 y D., 1994. The evolutionary ecology of mast seeding. Trends Ecol. Evol. 9: 465470.

Ke 11 y D., S or k V. L., 2002. Mast seeding in perennial plants: why, how, where? Ann. Rev. Ecol. Syst. 33: 427447.

K in d $1 \mathrm{~m}$ a n n P., B a l o u n o vá Z., 1999. Flowering regimes of terrestrial orchids: unpredic tability or regularity? J. Veg. Sci. 10: 269273.

M c K o n e M., K elly D., L e e W. G., 1998. Effect of climatic change on mast seeding species: frequency of mass flowering and escape from specialist insect predators. Global Change Biol. 4: 591596.

P o s t E., 2003. Large scale climate synchronizes the timing of flowering by multiple species. Ecology, 84: 277281.

S a take A., 2004. Modelling spatial dynamics of episodic and synchronous reproduction by plant population: the effect of small scale pollen coupling and large scale climate. Pop. Ecol. 46: 119128.

S a t a k e A., I w a s Y Y., 2000. Pollen coupling of forest trees: forming synchronized and perio dic reproduction out of chaos. J. Theor. Biol. 203: 6384.

$\mathrm{S}$ a t a ke A., I w a s a Y., 2002. The synchronized and intermittent reproduction of forest trees is mediated by the Moran effect, only in association with pollen coupling. J. Ecol. 90: 830838 .

Vor o n t z o v a L. I., Z a u g o ln ov a L. B., 1985. Population biology of steppe plants. [In:] The Population Structure of Vegetation. J. White (ed.). Dr W. Junk Publishers, Dordrecht, pp. 143178. 


\title{
Wielkoskalowe i drobnoskalowe czynniki kształtujące wzorce kwitnienia u długowiecznej byliny, starca wielkolistnego Senecio macrophyllus M.BIEB.
}

\begin{abstract}
Streszczenie
Celem badań było określenie, które z czynników środowiskowych wpływają na kształtowanie się wzorców kwitnienia u długowiecznej rośliny zielnej Senecio macrophyllus. Badania prowadzono w populacji na Białej Górze koło Tomaszowa Lubelskiego w latach 1989-2004. Wyniki pozwalają na stwierdzenie, że w kształtowaniu się wzorców reprodukcji w badanej populacji większe znaczenie mają drobnoskalowe czynniki środowiskowe (wilgotność i trofizm gleby, natężenie światła) niż czynniki wielkoskalowe (temperatura, opady), które w porównywalny sposób oddziałują na rośliny w całym areale populacji.
\end{abstract}


